\title{
Profitability Conditions of The Selected Companies from the Wig Food Industry Index in 2011-2018
}

\author{
Chrystian FIRLEJ, Sebastian KUBALA \\ Agricultural University of Kraków, Kraków, Poland \\ firlejchrystian@gmail.com, kubalas@uek.krakow.pl
}

\begin{abstract}
The development of a financial situation of a given company, in other words accounting liquidity has a direct impact on the shape of the current situation of an enterprise and the future prospects. The economic theory has not clearly defined so far a group of indexes that may be used for an objective analysis of the financial situation of the studied enterprise. The accounting liquidity directly influences the level of the enterprise profitability. In spite of dependency and correlation between profit and liquidity of an enterprise the two phenomena should be divided to a certain extent as they occure in two different time periods. In the process of management an increase of a profit does not always result in possessing greater financial resources. The conducted studies clearly indicate the specific companies belonging to the WIG-Food index in the years 2011-2018, which were characterised by the highest level of profitability. At the same time the companies with a low level of profitability were selected in the research process. The following profitability indexes were used in the study: return on sales (ROS), return on equity (ROE) and return on assets (ROA). The main aim of the studies was to indicate the factors responsible for development of profitability of the selected companies, which in the years 2011-2018 belonged to the WIG-Food index using the basic Du Pont model.
\end{abstract}

Keywords: profitability, food industry, wig index companies.

\section{$1 \quad$ Introduction}

The accounting liquidity and profitability play one of the most important roles during a development of a financial situation of the enterprise at present and in the future. The most effective management of the enterprise clearly reflects its level of profitability [7]. In order to present the assessment of the enterprise and its ability in the management proces, which aims at achieving profit from resources involved in conducting activity, we may use the profitability indexes, which are also defined as profitability indicators or rates of return. Unfortunately, in the economic theory a group of indexes that clearly and objectively present the financial situation of the enterprise have not been defined so far. While conducting the financial analysis of the enterprise there may be a problem due to a fact that the same value of the described index may be defined as a positive assessment for the enterprise while on the other hand it may generate negative 
assessment. In order to present the described phenomenon we use the accounting liquidity index, if its level is high it may indicate a positive situation of the enterprise and contribute to discharging its current obligations and at the same time may confirm the accumulation of excessive amount of cash which will be non-profit asset item. The second similar example may be the fixed assets rotation coefficient, which indicates if the enterprise uses their assets effectively or cannot afford to purchase the sufficient amount of fixed assets due to the little amount of capital [2]. Additionally, during conducting the financial analysis of the enterprise there may be indexes indicating the good condition of the enterprise and a few other indexes which describe it as negative. Therefore, it may be difficult to assess clearly enterprise financial condition. A good solution to counteract the negative assessment of the enterprise financial condition is to use proper models and algorithms during the conducted studies, which allows to show the cause-and-effect relationships between the selected financial indexes that appropriately assess the correctness of the enterprise activity [13].

The term profitability may be defined as a surplus of the enterprise revenue on sales over the cost of revenues [12], whereas the profitability measure is a relation of profits obtained by the enterprise to invested capital or to achieved effects coming from used production factors [4]. The enterprise profitability is directly connected with its accounting liquidity, which is the enterprise ability to timely payment of liabilities [7]. This ability is determined by the amount of funds committed in the enterprise most liquid assets. The level of ability to settle the enterprise current liabilities depends on the amount of the enterprise liquid assets, for example cash [11]. A weak financial position of the enterprise may be caused by a lot of factors, e.g. the decreasing level of the enterprise financial liquidity, increase of financial liabilities due to contractors or the increased level of receivables difficult to collect [3]. One of the most important factors that have a direct impact on the enterprise accounting liquidity (and its financial capacity) is profit. The described category may reflect the possibilities of the enterprise development and is a base of assessment of the effectiveness during the management process [8]. In spite of the interrelations between profit and accounting liquidity the term should be divided due to the fact that they do not usually exist at the same time. The level of profitability, especially its growth, not always results in increase of cash inflow. At the same time the improvement of the enterprise profitability does not always mean the improvement of the enterprise situation (the level of cash). In the longer period a lack of payment capability of the enterprise may lead to its insolvency, so it is very important to analyse the accounting liquidity. It is perceived as a necessary prerequisite and when it is fulfilled may assure further proper functioning of the enterprise [10]. The level of profitability and accounting liquidity of the enterprise decide about its future. There are cases of enterprises that were profitable at the moment of bankruptcy (lack of accounting liquidity). Agriculture is a specific section of economy in which accounting liquidity of the enterprise (agricultural enterprise) does not always have a significant impact on its profitability. The accounting liquidity in this area of economy is typically at a high level [5]. According to Wasilewski [9] an increase of the level of the fastly growing accounting liquidity may affect the level of the agricultural enterprise efficiency in the process of using fixed assets and own capital. The relation between the level of the enterprise accounting liquidity and its profitability 
has not been analysed adequately, which may justify a need to perform studies in this area.

\section{The Aim and the Research Methodology}

The main aim of the article is to present the factors responsible for developing profitability of the selected companies belonging to the WIG-Food index in the years 2011-2018 with the use of the basic Du Pont's model. As mentioned above, a basic measure that may be used for assessment of the financial condition of the enterprise is profitability index, including the return on equity ROE, which measures effectiveness of using a company's own capital. The proper high return on equity of the enterprise determines to a large extent its proper functioning and further development, which is largely of interest to the enterprise owners. The additional profitability indexes are return on assets and return on sales. Return on assets is a proportion of the enterprise net profit to the value of its assets. We can calculate it as a product of return on sales and asset turnover index. However, the return on sales is a profitability index that indicates how much net profit from sale remains in the enterprise. It ia a proportion of net profit (see income statement) to net sales revenue.

Unfortunately, a synthetic approach to the return on equity do not allow to create wider interpriting possibilities of the obtained results (net income/own capital). It only allows to determine if the indicated profitability level is a result of low equity level or high net income [1]. The structural system called 'indexes pyramid' creates better interpretation possibilities and allows to present cause and result dependencies. It also enables:

- to present the directions allowing to achieve an aim determined by the suitable synthetic index,

- presents a place of individual index in the system and indirectly in the economic reality.

The Du Pont model is a well-known form of profitability index of the pyramid structure. The Du Pond model was created by Frank Donaldson Brown who was an employee in the 'Du Pont' company. Donaldson Brown was responsible for the improvement of the car company 'General Motors' finances after the part of its shares was overtaken by 'Du Pont' enterprise. The model was the first system enabling planning and control of the company activity and until 1970 won the name of predominant tool during the financial analysis [6]. The original equasion looks as follows:

$($ Net income/sale $\times$ sale/total asset $=$ net income/total asset $=R O A)$

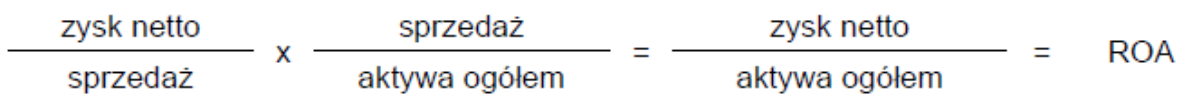

The research population used for the studies were the companies belonging to the WIGFood listed on the Warsaw Stock Exchange. The WIG-Food index belongs to the sector indexes and its companies also participate in the WIG index and at the same time are 
qualified to 'food sector. The date of beginning of WIG-Food index is 31 December 1998 and the value of the index on this day amounted to 1279,56 points. The subindex WIG-Food Methodology is the same as WIG index, that is total return index. When it is calculated both prices of its shares and revenues from dividents and pre-emptive rights are taken into account.

\section{The Current State and the Research Results}

The financial results of the selected WIG-Food companies in the years 2011-2017 were characterised by a significant diversity (table 1). During these years only five of them achieved a positive net result. The biggest net income in the years 2011-2012 and 2017 had Wawel S.A., in the other years GK ZT Kruszwica S.A. In the eight other analysed companies in the years 2011-2017 at least in one year there was net loss (the most loss, that is during four years, had: Agroton Public Limited, Milkiland NV or GK Pamapol S.A.). Milkiland NV company is characterised by a especially negative tendency in developing financial result as since 2014 it has had every year loss (since 2015 there has been a decreasing tendency of the loss).

Table 1. The financial results of the selected WIG-Food companies in the years 2011-2017.

\begin{tabular}{llllllll}
\hline & 2011 & 2012 & 2013 & 2014 & 2015 & 2016 & 2017 \\
\hline Agroton Public Limited & $\mathbf{- 2 1 1 9}$ & 6760 & $\mathbf{- 5 5 9 8}$ & $\mathbf{- 8 0 5 2 7}$ & $\mathbf{- 9 6 4 1}$ & 21755 & 8299 \\
GK Ambra S.A. & 19143 & 16032 & 16531 & 26047 & 19017 & 17869 & 23073 \\
GK Colian S.A. & 19534 & 46427 & 27434 & 20791 & 66822 & 39689 & $\mathbf{- 3 0 6 7 5}$ \\
KSG AGRO S.A. & 27140 & 8108 & $\mathbf{- 3 1 5 6 7}$ & $\mathbf{- 5 0 1 5 6}$ & $\mathbf{- 2 4 6 7}$ & 1831 & 358 \\
GK ZT Kruszwica S.A. & 29971 & 3413 & 106706 & 119841 & 93235 & 107581 & 41276 \\
Makarony Polskie S.A. & $\mathbf{- 3 3 4 7}$ & 1170 & 2900 & 4143 & 4914 & 5092 & 5517 \\
Milkiland NV & 14391 & 12771 & 10835 & $\mathbf{- 7 1 8 3 5}$ & $\mathbf{- 7 2 8 0 7}$ & $\mathbf{- 3 8 8 0 4}$ & $\mathbf{- 7 6 7 2}$ \\
GK ZPC Otmuchów S.A. & 8663 & 6523 & 4825 & 9441 & 3467 & $\mathbf{- 3 6 4 6 2}$ & $\mathbf{- 2 8 3 5}$ \\
Ovostar Union & 19671 & 23456 & 30589 & 25339 & 30954 & 22153 & 22457 \\
GK Pamapol S.A. & $\mathbf{- 2 6 5 4}$ & $\mathbf{- 3 2 9 6}$ & $\mathbf{- 2 3 7 5 3}$ & 606 & 1071 & 3205 & $\mathbf{- 2 3 5 1}$ \\
Pepees S.A. & 8594 & 1895 & 654 & 3373 & 5288 & 17600 & 13364 \\
Seko S.A. & $\mathbf{- 4 6 6 3}$ & 2068 & 5274 & 4589 & 5021 & 4485 & 9007 \\
Wawel S.A. & 56783 & 66668 & 80467 & 88035 & 92868 & 85086 & 113322 \\
& Negative financial result (bold) & & & \\
\hline
\end{tabular}

In order to show the differences in the conditions of factors influencing the level of development of return on equity in the selected WIG-Food companies the basic Du Pont model was used at the first stage (table 2).

According to the data presented in table 2 the return on equity was significantly differentiated in the years 2011-2017. It resulted from the changes in the level of return on equity in the analysed period. The influence of the equity multiplier was definitely smaller. 
The highest level of return on equity was observed in the Ovostar Union company (the average level of ROE amounted to $26,8 \%$ ), except for 2014 when the value of the company KSG AGRO S.A. return on equity was 348,0\% and 2016 when the ROE of the company Agroton Public Limited was 30,7\%. The Wawel S.A. company also had high values of the return on equity in the years 2011-2017 (the values of the index ranged from $15,5 \%$ to $21,6 \%$ ). The lowest ROE was observed in the Milkiland NV company.

The similar tendencies were in case of return on assets which is an arithmetic product of return on sales ROS and asset turnover index. The highest level of ROA was observed in the years 2012-2015 and in 2017 in the Ovostar Union company (the value of the index in these years ranged from $17,1 \%$ to $30,7 \%$ ), in 2011 in the KSG AGRO S.A. company $(\mathrm{ROA}=22,3 \%)$, and in 2016 in the Agroton Public Limited company $(\mathrm{ROA}=26,6 \%)$. The biggest negative values of the returns on assets was in 2014 (for the Agroton Public Limited company ROA amounted to $-82,2 \%$, and for the KSG AGRO S.A. company ROA amounted to $-54,8 \%$ ). The high values of the return on assets as well as return on equity were observed in the Wawel S.A. company.

The return on equity multiplier in the years 2011-2017 remained in the majority of companies at the same level. The standard deviation level in 11 companies ranged from 0,1 to 0,5 , with the exception of KSG Agro S.A. and Milkiland NV companies (in these entities the standard deviation amounted to 4,6 and 10,2). The highest leverage effect was observed in the Milkiland NV company in 2016 and 2017 (successively 29,0 and $13,7)$.

Table 2. Du Pont Analysis of the selected WIG-Food companies in the years 2011-2017.

\begin{tabular}{lrrrrrrr}
\hline & 2011 & 2012 & 2013 & 2014 & 2015 & 2016 & 2017 \\
\hline Agroton Public Limited & $-1.8 \% 1$ & $5.4 \%$ & $-4.6 \%$ & $-181.2 \%$ & $-21.0 \%$ & $30.7 \%$ & $10.4 \%$ \\
GK Ambra S.A. & $9.6 \%$ & $7.8 \%$ & $7.8 \%$ & $11.5 \%$ & $8.2 \%$ & $7.4 \%$ & $9.3 \%$ \\
GK Colian S.A. & $3.2 \%$ & $7.3 \%$ & $4.1 \%$ & $2.6 \%$ & $7.8 \%$ & $4.5 \%$ & $-3.6 \%$ \\
KSG AGRO S.A. & $37.9 \%$ & $10.1 \%$ & $-64.8 \%$ & $348.0 \%$ & $19.2 \%$ & $-16.4 \%$ & $-2.8 \%$ \\
GK ZT Kruszwica S.A. & $4.6 \%$ & $0.5 \%$ & $14.5 \%$ & $15.1 \%$ & $11.2 \%$ & $15.6 \%$ & $6.1 \%$ \\
Makarony Polskie S.A. & $5.6 \%$ & $1.9 \%$ & $4.6 \%$ & $6.1 \%$ & $6.9 \%$ & $7.0 \%$ & $7.3 \%$ \\
Milkiland NV & $9.0 \%$ & $7.4 \%$ & $6.4 \%$ & $-78.0 \%$ & $-210.1 \%$ & $-668.5 \%$ & $-65.6 \%$ \\
GK ZPC Otmuchów S.A. & $7.3 \%$ & $5.2 \%$ & $3.7 \%$ & $6.8 \%$ & $2.4 \%$ & $-35.1 \%$ & $-2.8 \%$ \\
Ovostar Union & $24.2 \%$ & $22.4 \%$ & $22.6 \%$ & $30.6 \%$ & $40.7 \%$ & $25.8 \%$ & $21.6 \%$ \\
GK Pamapol S.A. & $2.2 \%$ & $-2.8 \%$ & $-25.2 \%$ & $0.6 \%$ & $1.0 \%$ & $2.9 \%$ & $-2.2 \%$ \\
Pepees S.A. & $9.5 \%$ & $2.1 \%$ & $0.7 \%$ & $3.2 \%$ & $4.8 \%$ & $13.7 \%$ & $9.5 \%$ \\
Seko S.A. & $-10.3 \%$ & $4.4 \%$ & $10.2 \%$ & $8.5 \%$ & $8.8 \%$ & $7.5 \%$ & $15.5 \%$ \\
Wawel S.A. & $21.6 \%$ & $21.3 \%$ & $21.6 \%$ & $20.5 \%$ & $18.9 \%$ & $15.5 \%$ & $18.0 \%$
\end{tabular}

according to the formula: return on sales ROS* asset turnover index*equity multiplier $=$ return on equity $\mathrm{ROE}$

In the profitability assessment it is appropriate to indicate the correlation between the partial factors and the basic index. This analysis aims at controlling the degree of 
influence of these factors on the basic index by determining their strength and direction. The differentiate method was used in the study. more precisely - three factors analysis on the ground of greater interpretation possibilities. Although this method has some drawbacks. including limited accuracy of measurement. it was admitted that its biggest benefit is general nature of the approach to the measurement of the analysis of the factors influencing the level of profitability.

The process of determining the influence of the analysed factors on the basic amount with the use of differentiate method is performed in a few stages. The final result aims at identifying the strength and direction of the impact of changes of the individual factors on the return on equity level. In order to calculate ROE. it is necessary to identify the impact of the change on the amount of deviation of the analysed phenomenon on the basis of the determined absolute deviation of the basic value.

According to the performed three factors analysis (table 3) in the years 2011-2017 in the selected WIG-Food companies the return on sales ROS changes significantly greater influenced on the ROE level than the other indexes (during these years in all analysed companies there were only five cases when the greatest influence had the asset turnover (in the companies: Wawel S.A. (twice). Makarony Polskie S.A.. Ovostar Union. Seko S.A.) and four cases when the greatest influence had the return on equity multiplier changes (in the companies: Milkiland NV (twice). KSG AGRO S.A.. GK Kruszwica S.A.). As regarding return on assets and equity multiplier in the significant majority a negative direction of strength was observed - in $44.9 \%$ possible cases (in case of return on sales - ROS - the negative direction was only observed in $6.4 \%$ possibilities).

Table 3. The strength of the impact of return on sales. assets turnover and the capital structure on return on equity on the basis of three factors analysis.

\begin{tabular}{|c|c|c|c|c|c|c|}
\hline \multicolumn{7}{|c|}{ Agroton Public Limited } \\
\hline & 2012 & 2013 & 2014 & 2015 & 2016 & 2017 \\
\hline ROS na ROE & 121.7 & 101.2 & 42.1 & 94.9 & 112.0 & 94.1 \\
\hline TAT na ROE & -20.4 & -3.0 & 27.0 & -0.8 & 6.9 & 5.7 \\
\hline ER na ROE & -1.2 & 1.8 & 30.9 & 5.9 & -18.9 & 0.2 \\
\hline \multicolumn{7}{|c|}{ GH Ambra S.A. } \\
\hline & 2012 & 2013 & 2014 & 2015 & 2016 & 2017 \\
\hline ROS na ROE & 104.5 & 1811.4 & 145.5 & 95.0 & 129.1 & 73.2 \\
\hline TAT na ROE & 20.5 & 1584.8 & -25.6 & -17.3 & -20.8 & 41.8 \\
\hline ER na ROE & -25.0 & -3296.2 & -19.9 & 22.4 & -8.3 & -15.1 \\
\hline \multicolumn{7}{|c|}{ GK Colian S.A. } \\
\hline & 2012 & 2013 & 2014 & 2015 & 2016 & 2017 \\
\hline ROS na ROE & 113.0 & 124.7 & 85.5 & 112.0 & 101.0 & 97.4 \\
\hline TAT na ROE & 9.7 & 8.0 & -31.3 & -3.2 & -2.3 & -1.5 \\
\hline ER na ROE & -22.7 & -32.7 & 45.9 & -8.8 & 1.3 & 4.0 \\
\hline
\end{tabular}




\begin{tabular}{|c|c|c|c|c|c|c|}
\hline \multicolumn{7}{|c|}{ KSG AGRO S.A. } \\
\hline & 2012 & 2013 & 2014 & 2015 & 2016 & 2017 \\
\hline ROS na ROE & 102.3 & 55.3 & -49.1 & 100.0 & 86.3 & 98.1 \\
\hline TAT na ROE & 9.6 & 3.1 & 0.1 & -1.6 & 11.6 & -0.8 \\
\hline ER na ROE & -11.9 & 41.6 & 149.0 & 1.6 & 2.2 & 2.7 \\
\hline \multicolumn{7}{|c|}{ GK Kruszwica S.A. } \\
\hline & 2012 & 2013 & 2014 & 2015 & 2016 & 2017 \\
\hline ROS na ROE & 102.3 & 120.0 & 558.1 & 69.2 & 35.0 & 105.2 \\
\hline TAT na ROE & -2.8 & 12.4 & 210.6 & 30.6 & -9.3 & -7.0 \\
\hline ER na ROE & 0.4 & -32.4 & -668.7 & 0.2 & 74.3 & 1.8 \\
\hline \multicolumn{7}{|c|}{ Makarony Polskie S.A. } \\
\hline & 2012 & 2013 & 2014 & 2015 & 2016 & 2017 \\
\hline ROS na ROE & 116.1 & 108.3 & 151.6 & 82.4 & 1212.8 & -188.6 \\
\hline TAT na ROE & -12.7 & 6.1 & -35.3 & 59.3 & -931.5 & 225.1 \\
\hline ER na ROE & -3.3 & -14.4 & -16.3 & -41.6 & -181.3 & 63.5 \\
\hline \multicolumn{7}{|c|}{ Milkiland NV } \\
\hline & 2012 & 2013 & 2014 & 2015 & 2016 & 2017 \\
\hline ROS na ROE & 74.8 & 201.9 & 66.5 & 31.6 & -14.0 & 88.0 \\
\hline TAT na ROE & -16.1 & -73.5 & 11.2 & -13.7 & -4.8 & -0.1 \\
\hline ER na ROE & 41.3 & -28.3 & 22.3 & 82.1 & 118.8 & 12.1 \\
\hline \multicolumn{7}{|c|}{ GK ZPC Otmuchów S.A. } \\
\hline & 2012 & 2013 & 2014 & 2015 & 2016 & 2017 \\
\hline ROS na ROE & 158.9 & 59.9 & 116.5 & 81.8 & 72.7 & 100.3 \\
\hline TAT na ROE & -64.2 & 12.7 & 3.2 & 15.0 & 11.0 & -0.9 \\
\hline ER na ROE & 5.3 & 27.4 & -19.7 & 3.2 & 16.3 & 0.6 \\
\hline \multicolumn{7}{|c|}{ Ovostar Union } \\
\hline & 2012 & 2013 & 2014 & 2015 & 2016 & 2017 \\
\hline ROS na ROE & 50.5 & 481.1 & -14.2 & 65.4 & 78.6 & 120.0 \\
\hline TAT na ROE & 49.9 & -696.7 & 98.5 & 5.3 & 15.6 & -28.9 \\
\hline ER na ROE & -0.4 & 315.7 & 15.7 & 29.2 & 5.9 & 8.9 \\
\hline \multicolumn{7}{|c|}{ GK Pamapol S.A. } \\
\hline & 2012 & 2013 & 2014 & 2015 & 2016 & 2017 \\
\hline ROS na ROE & 122.8 & 118.6 & 100.3 & 107.5 & 91.6 & 96.0 \\
\hline TAT na ROE & -4.3 & -4.0 & -0.3 & 45.2 & 4.6 & 6.0 \\
\hline ER na ROE & -18.5 & -14.6 & 0.0 & -52.7 & 3.8 & -2.0 \\
\hline
\end{tabular}




\begin{tabular}{|c|c|c|c|c|c|c|}
\hline \multicolumn{7}{|c|}{ Pepees S.A. } \\
\hline & 2012 & 2013 & 2014 & 2015 & 2016 & 2017 \\
\hline ROS na ROE & 105.2 & 95.9 & 118.7 & 59.0 & 83.9 & 119.4 \\
\hline TAT na ROE & -5.3 & 2.1 & -29.2 & 9.1 & 8.9 & -16.5 \\
\hline ER na ROE & 0.1 & 2.0 & 10.4 & 31.9 & 7.2 & -2.9 \\
\hline \multicolumn{7}{|c|}{ Seko S.A. } \\
\hline & 2012 & 2013 & 2014 & 2015 & 2016 & 2017 \\
\hline ROS na ROE & 97.2 & 112.9 & 87.3 & 22.7 & 119.8 & 82.1 \\
\hline TAT na ROE & 4.4 & -13.3 & -5.7 & 151.3 & 14.4 & 42.9 \\
\hline ER na ROE & -1.5 & 0.4 & 18.3 & -74.0 & -34.2 & -25.0 \\
\hline \multicolumn{7}{|c|}{ Wawel S.A. } \\
\hline & 2012 & 2013 & 2014 & 2015 & 2016 & 2017 \\
\hline ROS na ROE & 13.7 & 88.4 & -187.3 & 8.8 & 57.6 & 241.2 \\
\hline TAT na ROE & -241.5 & -39.3 & 202.0 & 89.6 & 17.2 & -103.2 \\
\hline ER na ROE & 209.8 & -245.1 & 85.4 & 1.5 & 25.1 & -38.0 \\
\hline
\end{tabular}

\section{Conclusion}

The conducted studies have proved that the basic operational activity and the achieved sales revenues are significantly important for the analyzed WIG-Food companies. The return on sales (ROS) has a decisive influence on the development of the return on equity level. The equity multiplier plays a relatively insignificant role. so it may be concluded that the leverage effect is of a marginal importance. On the basis of the conducted studies with the use of the three factors analysis. it may be concluded that in the years 2011-2017 the selected WIG Food companies [ROE level] were dependent. to a significant degree. on the changes taking place at the sales profitability (ROS) level in relation to the other factors. In the years 2011-2017 the level of equity return of the analysed companies was characterised by the large variation. which may influence on the proper functioning of the companies. The variations of the asset profitability level in the analysed time period were responsible for this state of affairs. The impact of the equity multiplier was definitely smaller than the direct influence of the variation of the asset profitability level. A very good example of the company with the high level of equity profitability in the years 2011-2017 was the Ovostar Union company. The high level of the return on equity ratio in the analysed period was also noticed in the Wawel S.A. company. The WIG food companies should be characterised by the proper management and transparency of their activities in order to provide the high profitability level. which directly influences on the possibility of keeping their position on the market and belonging to the index. 


\section{References}

1. Bednarski, L.. Borowiecki. R.. Duraj. J.. Kurtys. E.. Waśniewski. T.. Wersty B.: Analiza ekonomiczna przedsiębiorstwa. Wydawnictwo AE im. O. Langego. Wrocław. p. 85-90 (2001).

2. Brigham. E.F.: Podstawy zarządzania finansami. PWE. Warszawa. p. 66-85. (1996).

3. Gołębiewski. G.. Tłaczała. A.: Analiza ekonomiczno-finansowa w ujęciu praktycznym. Difin. Warszawa. p. 157 (2005).

4. Kaczamrek. T.: Zarządzanie płynnością finansów małych i średnich przedsiębiorstw - ujęcie praktyczne. Difin. Warszawa. p. 112 (2007).

5. Kisielińska. J.: Wykorzystanie metod wielowymiarowej analizy do oceny sytuacji finansowej gospodarstw rolniczych. Wieś i Rolnictwo. nr 4 (121). p. 83-95 (2003).

6. Really modified Du Pont analysis: five ways to improve return on equity. www.sbaer.uca.edu/research/sbida/2002/19pdf. last accessed 2018/10/04.

7. Sierpińska. M.. Jachna. T.: Ocena przedsiębiorstwa według standardów światowych. Wydawnictwo Naukowe PWN. Warszawa. p. 195 (2004).

8. Wasilewski. M.: Płynność finansowa a efektywność gospodarstw indywidualnych. Roczniki Nauk Rolniczych. Seria G - Ekonomika Rolnictwa. t. 92. z. 1. p. 231 (2005).

9. Wasilewski. M.: Poziom wskaźnika szybkiej płynności finansowej a efektywność przedsiębiorstw rolniczych. In: Zarządzanie finansami firm - teoria i praktyka. Prace Naukowe AE we Wrocławiu. Wrocław. nr 1159. p. 450 (2007).

10. Waśniewski. T.. Skoczylas. W.: Analiza przepływów środków pieniężnych - pomocą w zarządzaniu finansami przedsiębiorstwa. Rachunkowość. nr 6. p. 271. (1996).

11. Wawryszuk-Misztal. A.: Strategie zarządzania kapitałem obrotowym netto w przedsiębiorstwach-studium empiryczno-teoretyczne. Wydawnictwo UMCS. Lublin. p. 83 (2007).

12. Wskaźnik

rentowności. https://mfiles.pl/pl/index.php/Wska\%C5\%BAnik_rentowno\%C5\%9Bci. last accessed 2018/10/04.

13. Żwirbla. A.: Analiza według modelu Du Ponta - zastosowanie praktyczne. Rachunkowość. 1/2006. p. 10 (2006). 